\title{
Analysis of the Historic Caddo Ceramics from 41NA223 in Downtown Nacogdoches, Nacogdoches County, Texas
}

Timothy K. Perttula

Heritage Research Center, Stephen F. Austin State University

Follow this and additional works at: https://scholarworks.sfasu.edu/ita

Part of the American Material Culture Commons, Archaeological Anthropology Commons, Environmental Studies Commons, Other American Studies Commons, Other Arts and Humanities Commons, Other History of Art, Architecture, and Archaeology Commons, and the United States History Commons

Tell us how this article helped you.

This Article is brought to you for free and open access by the Center for Regional Heritage Research at SFA ScholarWorks. It has been accepted for inclusion in Index of Texas Archaeology: Open Access Gray Literature from the Lone Star State by an authorized editor of SFA ScholarWorks. For more information, please contact cdsscholarworks@sfasu.edu. 


\section{Analysis of the Historic Caddo Ceramics from 41NA223 in Downtown Nacogdoches, Nacogdoches County, Texas}

\section{Creative Commons License}

\section{(c) (1) (8)}

This work is licensed under a Creative Commons Attribution-NonCommercial 4.0 International License 


\title{
Analysis of the Historic Caddo Ceramics from 41NA223 in Downtown Nacogdoches, Nacogdoches County, Texas
}

\author{
Timothy K. Perttula
}

\section{INTRODUCTION AND PURPOSE OF THE STUDY}

In 1999, the late Dr. James E. Corbin of Stephen F. Austin University in Nacogdoches, Texas, recorded 4INA223 in a proposed parking lot associated with offices for the City of Nacogdoches. The site is located on the southern edge of an upland ridge ( $290 \mathrm{ft}$. amsl) between Banita Crcek and La Nana Creck, southward-flowing tributaries of the Angelina River, and the area around it has a number of commercial buildings.

During the course of development of the parking lot for the Counly Courthouse of Nacogdoches, Caddo ceramics, animal bones, and late $18^{\text {th }}$-early $19^{\text {th }}$ century European artifacts were found on the surface in disturbed contexts. Corbin initiated some limited archeological investigations in the parking lot area to determine what these artifacts rcpresented functionally and culturally, as well as to assess the contextual integrity of any remaining archaeological deposits (Corbin 1999). Although no final conclusions were ever reached, Corbin concluded that 4INA223 represented a protohistoric or historic Caddo site and/or the site of the 1804 Guadalupe del Pilar mission church (Middlebrook 2007:113).

In the course of those investigations-primarily a short trench and minimal hand excavations along the trench where a single pit feature (Feature 1) had been exposed-a small assemblage of Caddo ceramic shords (111 sherds and 60 sherdlets) wcre recovered from 41NA223. These sherds are the subject of this article.

The purpose of this study of the 41NA223 ceramics is two-fold. First, I wish to thoroughly analyze the sherd collection in stylistic and tcchnological terms to ascertain if the sherd collection is Historic Caddo in age, and if so, determine the general characteristics of this assemblagc. And second, since "understanding the Caddo ceramics of Historic natives will be essential for workers in this area" (Middlebrook 2007:114), particularly in unraveling the archacological signatures of different Caddo groups that lived in the Angelina River basin, I hoped to make some head way in comparing the nature of this Historic Caddo assemblage with other recently dcscribed Caddo sherd collections from Nacogdoches County and the Neches/Angelina river basins.

\section{ANALYSIS METHODS}

Detailed analysis of the ceramic sherds from 41 NA223 (Appendix 1) is based on differences in temper, typc of sherd (i.e., rim, body, or base), rim and lip form (cf. Brown 1996: Figure 2-12), decoration (if present), surface treatment (smoothing, burnishing, or polishing; see Rice 1987), and firing conditions (cf. Teltscr 1993). Sherd cross-sections were inspected macroscopically and with a $10 \mathrm{X}$ hand lens to determine the character of the paste and its inclusions. Determining the firing conditions is based on the identification of the firing core in the sherd cross-sections and the identification of oxidation patterns as dcfined in Teltser (1993:535-536 and Figure 2a-h).

More spccifically, the following attributes were employed in the analysis of the ccramics from 41NA223: (a) temper, the dcliberate and indeterminatc materials found in the paste (Rice 1987:411), including a variety of tempers (grog or crushed sherds, burned bone, hematite, and burned mussel shell) and "particulate malters of some size;" (b) although most of the sherds are small and thus from indeterminate vessel forms, where sherds were large enough, vesscl form categories include open containers (bowls and carinated bowls) and restricted containers, including jars and bottles. Other form attributes include rim profile (outflaring or cverted, direct or vertical, and inverted) and lip profile (rounded, flat, or folded to the exterior). 
There were no base sherds, so base shape could not be recorded. Observations on ceramic sherd crosssections permit consideration of oxidation patterns (Teltser 1993:Figure 2), namely the conditions under which a vesscl was fired and then cooled after firing. Finally, wall thickness was recorded in millimeters (mm), using a vernier caliper, along the mid-section of the sherd.

With respect to interior and exterior surface treatment on the sherds, the primary methods of finishing the surface ol Caddo vessels includes smoothing, burnishing, and polishing, although a few sherds may still have scraping marks from initial surface treatment work by the pottcr. Brushing, a popular method of roughening the surface of Middle, Late, and Historic Caddo cooking jars in the Neches/Angelina river basins with stiff bundles of grasses, is considered a decorative treatment here rather than solely a functional surface treatment (cf. Rice 1987:138). A roughened and brushed pot would certainly have becn easier to pick up and carry than would an unroughened or smoothed vessel, but because the brushing was applied to be an integral part of the decoration of both rim and body vessel surface, I de-emphasize it as a surface treatment. Smoothing creates "a finer and more regular surface... [and] has a matte rather than a lustrous surface" (Rice 1987:138). Burnishing creates an irregular lustrous finish marked by parallel facets left by the burnishing tool (perhaps a smoothed pebble or bone). A polished surface treatment is marked by a uniform and highly lustrous surface finish, done when the vessel is dry, but without "the pronounced parallel facets produced by burnishing leather-hard clay" (Ricc 1987:138).

The application of a hematite-rich clay slip, black after firing in a reducing environment, is another form of surface trealment noted in this asscmblage. The clay slip was typically applied to the vessel exterior, and then was burnished or polished after it was leather-hard or dry. In other instances, a kaolin-rich clay was applicd as a pigment to engraved ccramic vessels.

Decorative techniques prcsent in the 41NA223 ceramic sherd collection include engraving, incising, brushing, and neck banding, and on certain sherds, combinations of decorative lechniques (i.e., brushed-incised and brushed-appliqued) created the decorative elements and motifs. Engraving was done with a sharp tool when the vcssel was either leatherhard or after it was fired, while the other decorative techniques were executed with tools (incising with wood or bone sticks or dowels), by adding strips of clay to the wet body (appliqué), using frayed sticks or grass stems (brushing) across the vessel surface, or corrugating vesscl coils when the vessel was wet or still plastic to create a series of neck bands.

\section{THE HISTORIC CADDO CERAMICS FROM 41NA223}

The sherd assemblage from 41NA223 includes 111 sherds and 60 sherdlets, those sherds less than 1/4-inch on a side (Appendix 2). Other than a simple tabulation of the sherdlets, they were not examined for this ceramic study. There are 63 plain sherdsfive rims and 58 body sherds-and 48 decorated sherds (see Appendix 1).

\section{DECORATIONS ON THE CERAMIC VESSEL SHERDS}

The sherds from 41NA223 are readily separable into fine wares or utility wares, following the distinctions employed by Schambach and Miller (1984) in their analysis of the ceramics from the Historic Caddo Cedar Grove site in the Great Bend area in southwestern Arkansas. These distinctions include apparent differences in temper (or the amount and size of the temper), surface treatment, vessel forms, and decorative methods. Finc wares consist of engraved or engraved-slipped sherds from carinated bowls, bowls, and bottles. The fine ware sherds morc frequently will be smoothed, burnished, and/or polished on the extcrior vessel surface. Utility ware sherds generally are from jars and simple bowls used for the cooking and storage of foods, generally have a coarse temper, and lack burnishing, polishing, or slipping on interior and cxterior vessel surfaces. Such vesscl sherds are decorated with brushing, incising, punctations, and appliqued elements, either by themselves, or in combination with one or more of these decorative methods (sce Schambach and Miller 1984; Suhm and Jelks 1962). Of the 48 decorated sherds from $41 \mathrm{NA} 223,45.8 \%$ are from fine ware vessels (all with engraving), and the remaining dccoratcd sherds $(54.2 \%)$ are from utility ware vessels, most of these having brushed decorations.

\section{Engraved ( $n=22)$}

The 22 engraved sherds from 4lNA223 include nine rims and 13 body sherds. Each of the 
rims appears to be from a separate vessel. Four of the engraved sherds (including two bone-tempered rims) are from Patton Engraved vessels (Figure 1f), probably globular bowls. These have sets of horizontal, diagonal, or parallel engraved lines with either triangular or linear-shaped tick marks on the engraved lines. In two instances, a white kaolin clay pigment has been rubbed in the engraved lines. One of the Patton Engraved rim sherds (see Figure 1f) has a black slip on its exterior surface.

Patton Engraved is the principal engraved fine ware in all Historic Caddo Allen phase sites in the Neches and Angelina river basins (see Fields 1995; Middlebrook 2007:Table 1). Although this type of pottery is present in considerable numbers on post A.D. 1650 Allen phase sites, information is not currently readily available on when Patton Engraved vessels were no longer being manufactured by Hasinai Caddo groups living in the area around Nacogdoches. From its recovery at Spanish mission sites occupied until the carly 1770 s, it is known that it was made as late as the latter part of the $18^{\text {th }}$ century. The absence or lack of study of post-A.D. 1770
Caddo sites hinders a more refined terminal date for the manufacture of this distinctive fine ware (the work by Tom Middlebrook on the Plaza Principal in Nacogdoches may greatly clarify this issue), but it is possible that Patton Engraved vessels were made by Hasinai Caddo potters as long as they remained in the Nacogdoches area, that being the mid-1830s.

Based on comparisons with Natchitoches Engraved vessels from the site of Los Adaes (Gregory and Avery 2007:38, 40-41), six sherds from 41 NA223, including four rims (one of which has an exterior black slip) from bowls or carinated bowls, are from Natchitoches Engraved vessels (see Figure $1 \mathrm{~b}, \mathrm{~d}-\mathrm{e}, \mathrm{g})$. These have scrolls and hatched zones with scroll lines having small triangular tick marks, zig-zag lines on the rim (see Figure le), and another rim has a small negative oval within a narrow engraved panel. According to Middlebrook (2007:Table 1) Natchitoches Engraved sherds or vessels have been found in several other sites in $\mathrm{Na}$ cogdoches County, including Mayhew (69 sherds) on Bayou Loco and Joe Little on Attoyac Bayou (two vessels). Middlebrook (2007:114) also noted

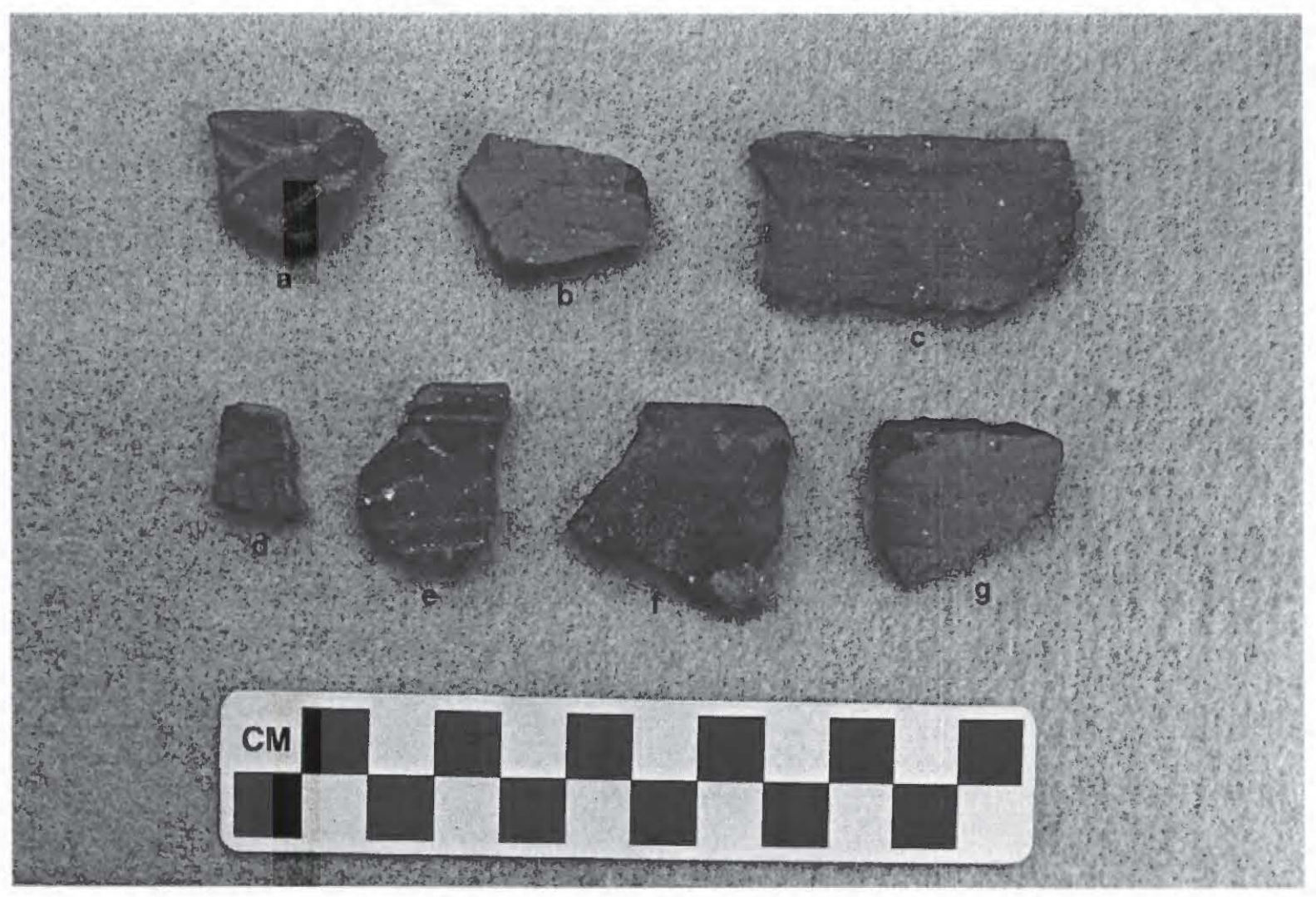

Figure 1. Engraved sherds from 41NA223: a, opposed curvilinear lines; b, d-e, g, Natchitoches Engraved; c, horizontal lines on the rim; f, Patton Engraved. Provenience: a, Lot 24; b, g, Lot 25; c, Lot 19; d, Lot 22; e, Lot 4; f, Lot 3 (see Appendix 1). 


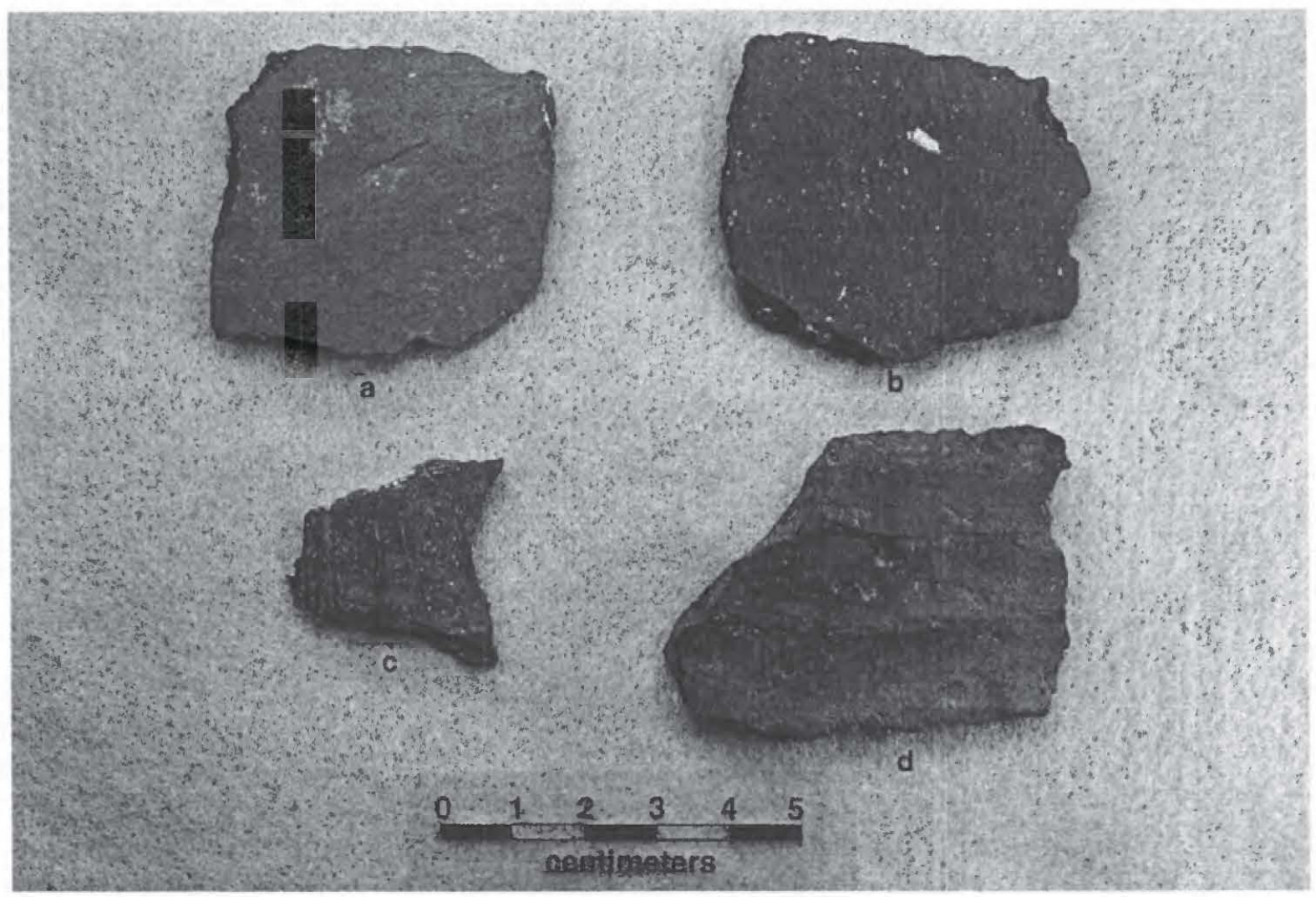

Figure 2. Decorated utility wares: a, overlapping brushed; b, parallel brushed; c, parallel incised lines; $d$, neck banded. Provenience: a, Lot 2; b, Lot 25; c, Lot 31; d, Lot 5.

that at least one Natchitoches Engraved vessel was found at the Luther Howell site in Sabine County, on the east side of Attoyac Bayou.

None of the other 12 engraved sherds can be confidently classified to a specific engraved Caddo pottery type, but none of them are from bottles. One rim has widely-spaced horizontal engraved lines (see Figure 1c), but no tick marks, while two other rims have either opposed lines or a combination of horizontal and vertical lines that created a zone filled with hatching. Indeterminate engraved body include one with opposed lines (see Figure 1a); two body sherds have widely-spaced curvilinear lines and a third with a single curvilinear line; two have single straight lines; two others have closely-spaced sets of parallel lines; and the last body sherd has opposed engraved lines on it.

\section{Brushed ( $n=17)$}

Most of the brushed sherds ( $n=14$ or $82 \%$ ) have parallel brushing marks (Figure $2 \mathrm{~b}$ ) on the body of jars. The remainder have overlapping brushing marks ( $n=3$, Figure 2a).

\section{Brushed-Incised $(\mathrm{n}=2)$}

Two body sherds have vertical brushing and incised lines below an area on the vessel that appears to have been deliberately roughened. The brushedincised decoration covered some portion of the body of cooking jars.

\section{Brushed-Appliqued ( $\mathrm{n}=1$ )}

The one brushed appliqued body sherd has parallel brushing on one side of a straight appliqued fillet. These elements are probably oriented vertically on the body of a cooking jar, and the appliqued fillets served to define a number of brushed panels on the vessel body surface.

\section{Incised ( $\mathbf{n = 5})$}

The incised sherds from 41NA223 have simple geometric designs, consisting of parallel incised lines with either close $(n=2)$ or widely-spaced $(n=2)$ lines (see Figure 2c) or broad opposing incised lines. The parallel incised decorative element (see Figure 2c) on 
one sherd may be part of a repeating set of vertical incised lincs on the body of a cooking jar, perhaps a style of Emory Punctated-Incised vessel (see Gregory and Avery 2007:55) common at Los Adaes.

Three of the incised sherds are from shcll-tempered vesscls, and thus they are likely from Eharb Incised vessels (see Gregory and Avery 2007:45-48) or from the body of Enory Punctated vessels that have both punctated (on the rim) and incised (on the body) decorative elements (sce Gregory and Avery 2007:55-56).

\section{Neck Banded ( $\mathrm{n}=1$ )}

The one ncck banded sherd has at least three horizontal rows of broad corrugations or neck bands (see Figure 2d) on what appears to be the lower part of a jar rim. Neck banding as a decoration is not particularly common in any prehistoric or historic Caddo sites in the Angelina river basin, but has becn reported in low numbers (i.e., $n=7$ sherds out of more than 20,000 decorated sherds) from Historic Caddo sites on Bayou Loco to the west (at Mayhew, Iron Rock, Loco Bottoms, Deshazo, and Henry M.) and at 41NA67 on Attoyac Bayou (Middlebrook 2007:Table 1).

\section{Plain Sherds}

The plain to decorated sherd ratio in the 41 NA223 sherd collection is 1.31:1 (63:48), indicating a relatively high proportion of decoration on both the rim and the body of a number of the vessels that were broken and discarded at the site. Still, the five plain rims (almost $36 \%$ of all the rims), and the proportion of plain to dccorated rims (1:1.8), suggests that plain vessels are a significant part of the ceramic assemblage at the sitc. At the same time, there arc no obvious plain wares with European influences (i.e., in shape or rim form) or "Rule of Two" plain wares (Gregory and Avery 2007:33-34 and 71-76) in the 41NA223 collection. The plain rims have rim and lip profiles consistent with bowl and jar lorms.

\section{Rim and Lip Form}

There are 14 rims in the small sherd collection, nine in the fine wares and five plain rims. Where rim form could be determined, the fine ware rims have either inverted $(n=3)$ or direcl $(n=4)$ rims from bowls or carinated bowls, while the plain vesscls have both everted $(n=2)$ and direct $(n=2)$ rims; the plain everted rims may be from wide-mouthed jars. With respect to the lip form of these rims, rounded lips are common in both the fine wares $(n=4)$ and plain wares ( $n=4)$, but flat lips ( $n=3$ ) and rounded, exterior folded lips $(n=2)$ are particularly characteristic of the fine wares from 41NA223.

\section{Use of Temper}

The 41 NA223 sherds are from vessels primarily tempered with crushed and burned bone, sometimes with a very coarse tcxturc. Approximately $82 \%$ of the sherds have hone temper, either by itself or in combination with grog or hematite inclusions (Table 1).

Why use bone as a temper? In addition to it likely being a matter of personal preference or part of a family stylistic tradition for particular Caddo potters, the addition of coarsc fragments of crushed bone (and hematite) would have made the clay morc plastic and increased its strength and use-life, properties that were important in the successful manufacture of durable pottcry vessels. For these--and probably other-reasons, the Caddo potters living primarily in the Angelina, Attoyac, and middle Sabine river basins in East Texas and northwest Louisiana chose bone as the principal tcmper in ceramic vessel manufacture and apparently shared a common ceramic heritage. These sites, all of which have abundant brushed pottery, date from Middle Caddo (ca. A.D. 1200-1400) to Historic Caddo times (Perttula 2002:370). They include prehistoric Caddo sites such as Washington Squarc (4INA49, 45\% hone tempcr), various sites at Lake Naconiche (40-60\% bone temper) on Naconiche Creek, sites at Lake Sam Rayburn ( $25-50 \%$ bone temper), and several sites at Toledo Bend Reservoir ( $76-86 \%$ bone temper). In the case of Historic Caddo sites, the Mayhew (41NA21), Steven Spradlcy (41NA206), and mission San Jose de los Nasoni sites (41RK191, 197, 200), also have high amounts of bone-tempered pottery (50-90\%). At Mission Dolores de los Ais, 80\% of the pottery there is bonc-tempered, but brushed pottery is absent (Perttula 2007:Table 1).

Hematite and grog are dccidedly secondary temper inclusions, sincc thcy occur most frequently in combination with large amounts of burned bonc. Slightly more than $5 \%$ of the 41 NA223 sherds are shell-tempered. The use of shell temper in Caddo ceramics from the Angelina River basin is a very rare occurrence (Tom Middlebrook, September 2007 personal communication), and it is likely that these 
Table 1. Temper in the 41NA223 sherds.

\begin{tabular}{|lrr|}
\hline Temper and pastc combinations & No. & Percent \\
\hline Bone/clay paste & 60 & 54.1 \\
Bone-hematite/clay paste & 15 & 13.5 \\
Grog-bone/clay paste & 9 & 8.1 \\
Bone/sandy paste & 7 & 6.3 \\
Shcll/clay paste & 5 & 4.5 \\
Grog/sandy paste & 3 & 2.7 \\
Grog-hematite/clay paste & 3 & 2.7 \\
Grog/clay paste & 2 & 1.8 \\
No tcmpcr/sandy paste & 2 & 1.8 \\
No tempcr/clay paste & 2 & 1.8 \\
Shell-hematitc/clay paste & 1 & 0.9 \\
Grog-hematite/sandy pastc & 1 & 0.9 \\
Hematite/sandy paste & 1 & 0.9 \\
& & \\
Total with bone temper & 91 & 82.0 \\
Total with hematile lemper & 21 & 19.0 \\
Total with grog temper & 18 & 16.2 \\
Total with shcll temper & 6 & 5.4 \\
Total with no tcmper & 4 & 3.6 \\
& & 87.4 \\
Total with clay/silt paste & 97 & 12.6 \\
Total with sandy paste & 14 & \\
\hline
\end{tabular}

sherds are from Historic Caddo vessels made along the Red River in northwestern Louisiana or in the Los Adaes area where shell-tempered vessels in $18^{\text {th }}$ and $19^{\text {th }}$ ceritury contexts arc quile abundant (see Girard 2007:Figure 1).

Sherds with a sandy paste account for $12.6 \%$ of the 41NA223 sherds (see Table 1). Most of these are either from utility ware sherds $(11.5 \%)$ or plain ware sherds $(15.9 \%)$, while only $4.5 \%$ of the fine wares have a sandy pastc. It is suspected that these differences are apparent because Caddo potters recognized that sandy clays hcld up better to heatrelated stresses and helped with vessel porosity and thermal conductivity, all beneficial in vessels designed to receive repeated use for cooking and healing foods and liquids.

\section{Surface Treatment}

Many of the sherds from 41 NA223 retain evidence of smoothing or burnishing on interior and/or exterior surfaces (Table 2 ). The fine wares are more frequently burnished on interior and extcrior vessel surfaces than cither the decorated utility wares or plain wares, while utility wares are most commonly smoothed on their interior surface.

The smoothing of utility ware interior vessel surfaces was probably donc to lower the permeability and increase the heating effectiveness of particular vessels in cooking tasks (cf. Rice 1996:148). With the fine wares, the well-smoothed or burnished interior surfaces may have been advantageous in the repeated use of these wares as food serving vesscls. The purpose of exterior smoothing and burnishing may have bcen for stylistic and display purposes, creating a flat and lustrous surface well-suited to highlight the cngraved (and sometimes pigment-filled) and slipped exterior surfaces of the fine warc vessels.

Plain wares represent an amalgam of the fine wares and utility wares in the 41 NA223 assemblagc (i.e., the plain sherds likely originatcd from both decorated utility wares and fine wares as well as plain vessels), and the surface treatment evidence reflects this. About $11 \%$ of the plain wares are 
Table 2. Surface Treatment in the 41NA223 sherds.

\begin{tabular}{|lccc|}
\hline Surface Treatment & Fine wares & Utility wares & Plain wares \\
\hline Interior smoothed & $18.2^{*}$ & 34.6 & 19.0 \\
Exterior smoothed & 18.2 & 7.7 & 15.9 \\
Interior Burnished & 40.9 & 3.8 & 7.9 \\
Exterior Burnished & 59.1 & 0.0 & 11.1 \\
\hline $\mathrm{N}$ & 22 & 26 & 63 \\
\hline *percentage & & & \\
\hline
\end{tabular}

burnished on their exterior surfaces-a much lower frequency ( 5 times less) than the fine wares-compared to about $8 \%$ on the interior vessel surfaces. Nevertheless, burnished surfaces on the plain rim and body sherds are at least two times more common than are burnished surfaces in the utility ware sherds (see Table 2). Between 16-19\% of the interior and exterior surfaces of the plain sherds are smoothed, very comparable to the dccorated fine ware sherds rather than the decorated utility ware sherds, as lcss than $8 \%$ of the latter are smoothed on the exterior surface. This data suggests that some of the plain wares were treated as fine wares-being wellsmoothed and burnished-but probably in other cases were also uscd for the serving and cooking of foods and liquids.

\section{Vessel Wall Thickness}

The vessel sherds from 41NA223 arc from relatively thin-walled and well-shaped vessels (Table 3). Rims range from $5.59-6.50 \mathrm{~mm}$ in mcan thickness, while body sherds range from $6.02-6.74 \mathrm{~mm}$ in mean thickness.

The finc ware vessel sherds are thinner than the decorated utility ware or plain ware sherds, particularly along the rim. Thesc variations in vessel wall thickness are likely related to functional and technological differences in how these different wares were intended to be used by Caddo potters. The more substantial vessel walls in the utility wares would be well suited to the cooking and heating of foods and liquids and would have contributed to their ability to withstand heat-rclated stresses. Fine wares were probably intended for use in the serving of foods and liquids.

Another factor that would influence vessel body wall thickncss would be the sequence in which a vessel was constructed (Krausc 2007:35). Vessels constructed from the bottom up, as these Historic Caddo vessels likely werc, would tend to have thinner walls moving up the vessel body towards the rim, with the lower portion of the vessel-especially the base-usually significantly thicker than the upper portions of the vesscl.

\section{FIRING CONDITIONS}

The Caddo vessel sherds from 41NA223 were fired primarily in a reducing or low oxygen environment, probably by smothering the vessel in a bed of coals from a wood fire. This method of firing is typical of Caddo ceramic assemblages throughout East Texas. After firing, most of the vessels were apparently cooled in a high oxygen environment (cspecially the plain wares and the finc wares), meaning that the fire-hardened vessels were

Table 3. Mean thickness of sherds (in mm) in the 41 A223 ceramic assemblage.

\begin{tabular}{|lccc|}
\hline Sherd Type & Fine wares & Utility wares & Plain wares \\
\hline Rim & $5.59 \pm 0.37$ & - & $6.50 \pm 0.96$ \\
Body & $6.02 \pm 0.86$ & $6.74 \pm 0.79$ & $6.66 \pm 0.88$ \\
\hline
\end{tabular}


probably removed from the fire to cool, producing a thin oxidized or lighter surlace on either one (i.e., firing conditions $\mathrm{G}$ and $\mathrm{H}$ ) or both (i.e., firing condition F) vessel surface (Table 4).

The consistency in how the vessels al 41NA223 were fired indicates that the Caddo potters who made those vessels werc well-versed in regulating firing and cooling temperatures as well as maintaining control over the final finished end product, namely the manufacture of durable and relativcly hard vessels.

\section{Instrumental Neutron Activation Analysis}

A Patton Engraved rim sherd (see Figure 1f) was subjected to instrumental neutron activation analysis by the Missouri University Research Reactor as part of a continuing study of the production and exchange of ceramic pottcry vessels between different Caddo and non-Caddo groups (cf. Perttula 2002). This analysis indicates that this vessel was made from local clays, probably alluvial clays (Jcffrcy Ferguson, August 2007 personal communication). Sherds from vessels made with similar local clays include examples from the ncarby Washington Square site and the Henry M. site; this latter site was occupied during Historic Caddo times (Middlebrook 2007:Table 1).

\section{CONCLUSIONS}

The Caddo ccramic vessel sherds from 41NA223 are from vessels made during the Historic Caddo period: the identification of both Patton Engraved and Natchitoches Engraved sherds in the collection substantiate that conclusion. Other than engraved wares, the decorated utility wares principally consist of vessels decorated with brushed, or brushed-incised and brushed-appliqued elcments. Proportionally, however, the amount of brushed pottery among cither all the decorated sherds $(41.7 \%)$ or among all the sherds $(18.1 \%)$ is not particularly abundant (see below). The absolute age of the ceramics from the site remain uncertain, but because of the association of the Caddo ceramics with archaeological deposits (especially Fcaturc 1) containing late $18^{\text {th }}$ to early $19^{\text {th }}$ century European artifacts, I am inclined to view the 41NA223 Caddo ceramics as belonging to an assemblage made by a Caddo group between ca. A.D. 1750-1800.

The 4INA223 sherds are from engraved and/or slipped fine ware vesscls (bowls and carinated bowls), wet-paste decorated utility ware vessels (jars and simple bowls), and plain wares (bowls and jars). The vessels are thin-walled forms tempered primarily with bone, fircd principally in a low oxygen or reducing environment, and were either burnished (in the case of the finc wares) or smoothed (in the case of a number of the utility ware sherds) on one or both vessel surfaces. These vessels were probably made from local clays, except for the few shcll-tempered vessel sherds among the utility ware and plain ware collections. These shell-tempered vesscls may have been obtained from other Caddo groups living in north Louisiana (see Girard 2007; Gregory and Avery 2007).

Are there any hints in the 41 NA223 ceramic assemblagc as to which Caddo group may have made the ceramics found at the site? Middlebrook (2007:Table 1) has provided a useful mcans of comparison between generally contemporaneous Historic Caddo sites by focusing on threc attributes of assemblages: (1) the percentage of brushed

Table 4. Firing Conditions in the 41NA223 sherds.

\begin{tabular}{|lccc|}
\hline Firing Condition* & Fine wares & Utility wares & Plain wares \\
\hline Oxidizcd (A) & $18.2 * *$ & 0.0 & 4.8 \\
$\begin{array}{l}\text { Incomplctely Oxidized } \\
\text { (C-E) }\end{array}$ & 4.5 & 7.7 & 3.2 \\
$\begin{array}{l}\text { Reducing (B) } \\
\text { Reducing, but cooled }\end{array}$ & 13.6 & 50.0 & 27.0 \\
$\begin{array}{l}\text { in the open air (F-H) } \\
\text { Totals }\end{array}$ & 63.6 & 42.3 & 65.1 \\
\hline *Firing condition calegories (A-H) follow Tcltser (1993:Figure 2a-h) & \\
**percentage & 22 & 63 \\
\hline
\end{tabular}


sherds; (2) the ratio of brushed to plain sherds; and (3) the percentage of brushed sherds divided by the percentages of brushed and plain sherds in a particular assemblage. Table 5 compares the attributes of the 41NA223 sherd assemblage-albeit a very small collection compared to the others listed herc, and thus probably affected by sample size issues-with 11 other Historic Caddo sites in the Angelina River, Bayou Loco, Lcgg Creek, and Attoyac Bayou drainages. The differences between the sites are intriguing.

The first and most obvious difference between the 41 NA223 ceramic assemblage and most of the other Historic Caddo sites (with the notable exception of 41NA67 in the Attoyac Bayou basin) is the low percentage of brushed pottery here, and the relative abundance of plain pottery sherds. The low percentage of brushed pottery also contributes to the miniscule Brushed/Plain ratio at 41NA223, and a low \% Brushed/Brushed + Plain value. In the Bayou Loco,
Angelina River, and Legg Creck Caddo sites, brushed pottery is very abundant and a pervasive feature of these Nacogdoches County Caddo occupations. The only Historic Caddo site with a somewhat comparable ceramic assemblage to that from 41NA223 is from 41NA67 at Lake Sam Rayburn (Middlebrook 2007:113). There, the number of brushed sherds $(n=33)$ is dwarfed by plain sherds $(n=275)$ as well as incised $(n=72)$ and punctated $(n=37)$ sherds (according to Middlebrook [2007:113], because of the multi-component nature of the site, it is not clear what proportion of these sherds can be associatcd with the Historic Caddo occupation); incised and punctated sherds are far from common at 41NA223. Brushed sherds comprise only $7.2 \%$ of the 458 sherds from 41 NA67 (see Table 5).

On the basis of Table 5, it is not possible to currently link on geographical grounds the 41NA223 Historic Caddo ceramic assemblage with Caddo

Table 5. Comparisons with selected other Historic Caddo sites in Nacogdoches County, Texas.

\begin{tabular}{|c|c|c|c|}
\hline Site* & $\%$ Brushed** & Brushed/Plain & $\%$ Brushed/Brushed + Plain \\
\hline 41NA223 & 18.1 & 0.32 & 24.2 \\
\hline \multicolumn{4}{|c|}{ Angelina River sites } \\
\hline 41NA6 & 65.1 & 4.61 & 82.2 \\
\hline 41NA 15 & 54.0 & 4.29 & 81.1 \\
\hline 41NA54 & 70.2 & 3.8 & 79.0 \\
\hline \multicolumn{4}{|c|}{ Bayou Loco sites } \\
\hline $41 \mathrm{NA} 21$ & 46.2 & 1.21 & 54.7 \\
\hline 41 NA22 & 48.7 & 1.34 & 57.3 \\
\hline 41 NA23 & 43.0 & 1.15 & 53.5 \\
\hline $41 N A 27$ & 66.1 & 2.9 & 74.3 \\
\hline $41 N A 60$ & 63.4 & 5.2 & 83.9 \\
\hline 41NA111 & 69.4 & 5.44 & 84.5 \\
\hline \multicolumn{4}{|l|}{ Legg Creek } \\
\hline 41NA44 & 34.1 & 1.07 & 51.8 \\
\hline \multicolumn{4}{|c|}{ Attoyac Bayou } \\
\hline 41NA67 & 7.2 & 0.12 & 10.7 \\
\hline \multicolumn{4}{|c|}{$\begin{array}{l}\text { * Except for } 41 \text { NA223, the sherd data from the other listed sites is from Middlebrook ( } 2007 \text { :Table 1); } \\
\text { **\% Brushed is the percentage of all sherds with brushing as the only surface treatment; } \\
\text { Brushed/Plain is the ratio of brushed sherds to plain or undecorated sherds; and } \\
\% \text { Brushed/Brushed + Plain is the percentage of the sherds with brushing compared to all the sherds } \\
\text { in a collection that do not have "more claborate decorative styles such as incised, engraved, or punc- } \\
\text { tated" (Middlebrook 2007:101). }\end{array}$} \\
\hline
\end{tabular}


groups living in the Angelina, Bayou Loco, Legg Creek, or Attoyac Bayou drainagc basins, situated either in the western half of Nacogdoches County or in the far southeastern part of the county. It is crucial that well-studied Historic Caddo ceramic assemblages be obtained from the La Nana and Banita creeks area in the central part of the countyfor instance, from the Spradley site (41NA206), downstream a few miles from 41 NA223 on La Nana creek-as that may be where the ethnic affiliations lie of the Caddo potters that madc the distinctive Caddo pottery found at the possible site of the Guadalupe del Pilar mission church.

\section{ACKNOWLEDGMENTS}

I would like to thank Dr. Leslie Cecil and Dr. Gcorge Avery of Stephen F. Austin State University for permission to study this Historic Caddo sherd collcction gathered by the late Dr. James E. Corbin. Thanks also to Tom Middlcbrook, Shawn Marceaux, and Mark Walters for comments on the draft version of the report. Bo Nclson took the photographs of the decorated sherds.

\section{REFERENCES CITED}

Brown, J. A.

1996 The Spiro Ceremonial Center: The Archaeology of Arkansas Valley Caddoan Culture in Eastern Oklahoma. Mernoirs No. 29. Museum of Anthropology, University of Michigan. Ann Arbor.

Corbin, J. E.

1999 A Brief Archacological Survey of the Proposed Site of the Nacogdoches County Court House Parking Lot (41NA223), Nacogdoches County, Texas. MS on file, Stephen F. Austin State University, Nacogdoches, Texas.

Fields, R. C.

1995 Analysis of Native-Made Ceramics. In The Deshazo Site, Nacogdoches County, Texas, Volume 2: Artifacts of Native Manufacture, edited by D. A. Story. pp. 173-232. Studies in Archeology 21. Texas Archeological Research Laboratory, The University of 'Texas at Austin.

Girard, J. S.

2007 Sites in Northern Louisiana with Major Collections of Historic Caddo and Other Native American Pottery. Journal of Northeast Texas Archaeology 26:24-32.
Gregory, H. F. and G. Avery

2007 American Indian Pottery from Historic Period Sites in North Louisiana. Journal of Northeast Texas Archaeology 26:33-76.

Krause, R. A.

20077 A Potter's Tale. In Plains Village Archaeology: Bison-hunting Farmers in the Central and Northern Plains, edited by S. A. Ahler and M. Kay, pp. 32-40. University of Utah Press, Salt Lake City.

Middlebrook, $\mathrm{T}$.

2007 A Survey of Historic Caddo Sites in Nacogdoches County. Journal of Northeast Texas Archaeology 26:99-115.

Perttula, T. K.

2002 Archaeological Evidence for the Long-Distance Exchange of Caddo Indian Ceramics in the Southern Plains, Midwest, and Southeastern United States. In Geochemical Evidence for Long-Distance Exchange, edited by M. D. Glascock, pp. 89-107. Bergin and Garvey, Westport. Connecticut.

2007 One Attempt at Defining Allen Phase Ceramic Subclusters. Journal of Northeast Texas Archaeology 26:77-81.

Perttula, T. K. (editor)

2002 Archeological Investigations at the Proposed Lake Naconiche, Nacogdoches County, Texas. 2 Vols. Report of Investigations No. 42. Archeological and Environmental Consultants, Austin.

Rice, P. M.

1987 Pottery Analysis: A Sourcebook. University of Chicago Press, Chicago.

1996 Recent Ceramic Analysis: 1. Function, Style, and Origins. Journal of Archaeological Research 4(2):133-163.

Schambach, F. F. and J. E. Miller

1984 A Description and Analysis of the Ceramics. In Cedar Grove: An Interdisciplinary Investigation of a Late Caddo Farmstead in the Red River Valley, edited by N. L. Trubowitz, pp. 109-170. Research Series No. 23. Arkansas Archeological Survey, Fayetteville.

Suhm, D. A. and E. B. Jelks (editors)

1962 Handbook of Texas Archeology: Type Descriptions. Special Publication No. 1, Texas Archeological Society, and Bulletin No. 4, Texas Memorial Museum, Austin.

Teltser, P. A.

1993 An Analytic Stratcgy for Studying Assemblage-Scale Ceramic Variation: A Case Study from Southeast Missouri. American Antiquity 58(3):530-543. 
APPENDIX 1, DETAILED ATTRIBUTE ANALYSIS

\begin{tabular}{|c|c|c|c|c|c|c|}
\hline Provenience & Sherd & $\begin{array}{l}\text { Temper } \\
\text { Type* }\end{array}$ & $\mathrm{FC}$ & ST & $\begin{array}{l}\text { Th } \\
(\mathrm{mm})\end{array}$ & Decoration \\
\hline \multirow[t]{23}{*}{ Lot 0} & \multicolumn{6}{|c|}{ Surface, $0-10 \mathrm{~cm}$} \\
\hline & body & $b$ & G & - & 6.0 & plain \\
\hline & body & $\mathrm{b}$ & $\mathrm{G}$ & - & 5.4 & plain \\
\hline & body & $b$ & A & - & 7.1 & plain \\
\hline & body & $b$ & $\mathrm{H}$ & - & 6.7 & plain \\
\hline & body & g-b & B & - & 7.2 & plain \\
\hline & body & $\mathrm{b}$ & $\mathrm{F}$ & I SM & 6.5 & plain \\
\hline & body & $\mathrm{b}$ & B & - & 8.3 & plain \\
\hline & body & $b$ & G & - & 5.9 & plain \\
\hline & $\begin{array}{l}\text { rim, } \\
\text { EV-RO }\end{array}$ & none & G & - & 6.3 & plain \\
\hline & body & b & $\mathrm{G}$ & - & 6.2 & plain \\
\hline & body & b & $\mathrm{H}$ & E SM & 5.2 & plain \\
\hline & body & $\mathrm{g}$ & $\mathrm{G}$ & - & 8.1 & plain \\
\hline & body & $\mathrm{b}$ & $\mathrm{F}$ & I SM & 7.5 & plain \\
\hline & body & none & $\mathrm{H}$ & $\mathrm{I} / \mathrm{E} \mathrm{B}$ & 4.6 & single curvilinear engraved line \\
\hline & body & $\mathrm{g}$ & $\mathrm{F}$ & - & 6.2 & $\begin{array}{l}\text { parallel and widely-spaced } \\
\text { incised lines }\end{array}$ \\
\hline & body & g-h & A & - & 6.3 & $\begin{array}{l}\text { curvilinear and widely-spaced } \\
\text { cngraved lines }\end{array}$ \\
\hline & body & b & $\mathrm{H}$ & E SM & 4.5 & $\begin{array}{l}\text { horizontal and diagonal } \\
\text { engraved lines; linear tick } \\
\text { marks on diagonal line; white } \\
\text { pigment rubbed in engraved } \\
\text { lincs }\end{array}$ \\
\hline & body & none & B & - & 6.0 & $\begin{array}{l}\text { closely spaced parallel } \\
\text { engraved lines; cf. Patton } \\
\text { Engraved }\end{array}$ \\
\hline & body & sh & $\mathrm{F}$ & - & 6.5 & $\begin{array}{l}\text { parallel and closely-spaced } \\
\text { incised lines }\end{array}$ \\
\hline & body & b & B & - & 7.5 & parallel brushed \\
\hline & body & b & B & - & 7.2 & parallel brushed \\
\hline & body & b & B & - & 8.8 & parallel brushed \\
\hline \multirow[t]{6}{*}{ Lot 1} & \multicolumn{6}{|c|}{ Surfacc, $0-10 \mathrm{~cm}$} \\
\hline & body & sh & B & - & 6.2 & $\begin{array}{l}\text { parallel and widcly-spaced } \\
\text { incised lines }\end{array}$ \\
\hline & body & $\mathrm{g}$ & $\mathrm{F}$ & I SM & 5.4 & overlapping brushed \\
\hline & body & b & G & I SM & 7.1 & overlapping brushed \\
\hline & $\begin{array}{l}\text { rim, } \\
\text { INV-FL }\end{array}$ & $b$ & $\mathrm{~F}$ & $\mathrm{I} / \mathrm{E} \mathrm{B}$ & 6.5 & $\begin{array}{l}\text { horizontal and vertical } \\
\text { engraved lines and } \\
\text { horizontal hatched zone }\end{array}$ \\
\hline & $\begin{array}{l}\text { rim, } \\
\text {-FL }\end{array}$ & $b-h$ & A & E B & 5.7 & $\begin{array}{l}\text { horizontal engraved lines with } \\
\text { linear and triangular tick } \\
\text { marks, Patton Engraved }\end{array}$ \\
\hline
\end{tabular}




\begin{tabular}{|c|c|c|c|c|c|c|}
\hline Provenience & Sherd & $\begin{array}{l}\text { Temper } \\
\text { Type* }\end{array}$ & $\mathrm{FC}$ & ST & $\begin{array}{l}\text { Th } \\
(\mathrm{mm})\end{array}$ & Decoration \\
\hline \multirow[t]{12}{*}{ Lot 1 , cont. } & body & b-h & $\mathrm{F}$ & VE B & 8.8 & plain \\
\hline & body & $\mathrm{b}$ & $\mathrm{F}$ & I SM & 6.3 & plain \\
\hline & body & b & G & - & 5.9 & plain \\
\hline & body & $\mathrm{b}$ & $\mathrm{H}$ & - & 6.5 & plain \\
\hline & body & b & G & E SM & 5.9 & plain \\
\hline & body & $\mathrm{b}$ & $\mathrm{C}$ & - & 8.2 & plain \\
\hline & body & $g-b$ & A & I SM & 7.1 & plain \\
\hline & body & b & $\mathrm{D}$ & - & 6.6 & plain \\
\hline & body & $\mathrm{b}$ & $\mathrm{B}$ & I B & 4.9 & plain \\
\hline & body & b & $\mathrm{G}$ & - & 8.1 & plain \\
\hline & body, & sh-h & $\mathrm{F}$ & - & 4.6 & plain \\
\hline & $\begin{array}{l}\text { Bt rim, } \\
\text { D-RO }\end{array}$ & b-h & $\mathrm{G}$ & I SM & 7.1 & plain \\
\hline \multirow[t]{2}{*}{ Lot 2} & \multicolumn{6}{|c|}{ Surface, $0-10 \mathrm{~cm}$} \\
\hline & body & $\mathrm{b}$ & B & - & 7.5 & overlapping brushed \\
\hline \multirow[t]{4}{*}{ Lot 3} & \multicolumn{6}{|c|}{ Surface, $0-10 \mathrm{~cm}$} \\
\hline & $\begin{array}{l}\text { rim, } \\
\text { INV-RO }\end{array}$ & $\mathrm{b}$ & A & V/E B & 5.6 & $\begin{array}{l}\text { Patton Engraved, horizontal } \\
\text { engraved line with triangular } \\
\text { tick marks; black cxt. slip }\end{array}$ \\
\hline & body** & $\mathrm{b}$ & $\mathrm{H}$ & E SM & 7.2 & vertical roughened \\
\hline & body** & b & $\mathrm{H}$ & I/E SM & 6.3 & $\begin{array}{l}\text { vertical roughencd and } \\
\text { diagonal brushed-inciscd }\end{array}$ \\
\hline \multirow[t]{2}{*}{ Lot 4} & \multicolumn{6}{|c|}{ Surface, $0-10 \mathrm{~cm}$} \\
\hline & $\begin{array}{l}\text { rim, } \\
\text { D-RO, ex }\end{array}$ & $f^{b-h}$ & $\mathrm{H}$ & L/E B & 5.2 & $\begin{array}{l}\text { cf. Natchitoches Engraved; } \\
\text { zig-zag lincs in panel defined } \\
\text { hy horizontal engraved lines }\end{array}$ \\
\hline \multirow[t]{2}{*}{ Lot 5} & \multicolumn{6}{|c|}{ Surface, $0-10 \mathrm{~cm}$} \\
\hline & body & h & B & I B & 7.7 & $\begin{array}{l}\text { 3+ rows of neck bands; } \\
\text { La Rue Neck Banded }\end{array}$ \\
\hline \multirow[t]{10}{*}{ Lot 7} & \multicolumn{6}{|c|}{ N99/E90, profile } \\
\hline & body & $b$ & B & - & 6.5 & plain \\
\hline & body & b & $\mathrm{H}$ & - & 9.8 & plain \\
\hline & body & $g-b$ & G & I/E B & 6.3 & plain \\
\hline & body & g-h & $\mathrm{F}$ & - & 5.7 & plain \\
\hline & body & $\mathrm{b}$ & $\mathrm{B}$ & E SM & 5.8 & plain \\
\hline & body & $\mathrm{b}$ & G & - & 5.2 & plain \\
\hline & body & $\mathrm{b}$ & $\mathrm{G}$ & I SM & 4.6 & plain \\
\hline & body & $b-h$ & $\mathrm{~B}$ & I SM & 6.5 & plain \\
\hline & body & b & $\mathrm{H}$ & I SM & 6.0 & plain \\
\hline
\end{tabular}




\begin{tabular}{|c|c|c|c|c|c|c|}
\hline Provenience & Sherd & $\begin{array}{l}\text { Temper } \\
\text { Type* }\end{array}$ & FC & ST & $\begin{array}{l}\text { Th } \\
(\mathrm{mm})\end{array}$ & Decoration \\
\hline \multirow[t]{3}{*}{ Lot 7, cont. } & body & b & B & E SM & 6.6 & plain \\
\hline & rim, -RO & b-g & $\mathrm{F}$ & - & 8.3 & plain \\
\hline & body & b-h & F & E B & 6.5 & $\begin{array}{l}\text { curvilinear and widely-spaced } \\
\text { engraved lines }\end{array}$ \\
\hline \multirow[t]{2}{*}{ Lot 8} & \multicolumn{6}{|c|}{ Fealure 1, back dirt } \\
\hline & rim & g-b & F & - & 4.5 & plain \\
\hline \multirow[t]{2}{*}{ Lot 9} & \multicolumn{6}{|c|}{ N99/E90, trench } \\
\hline & body & sh & $\mathrm{F}$ & - & 6.2 & plain \\
\hline \multirow[t]{2}{*}{ Lot 10} & \multicolumn{6}{|c|}{ N99/E90, profile trench } \\
\hline & body & $\mathrm{b}$ & $\mathrm{B}$ & - & 6.8 & plain \\
\hline \multirow[t]{5}{*}{ Lot 11} & \multicolumn{6}{|c|}{ N99/E90, fill from Fcature 1} \\
\hline & body & $b$ & $\mathrm{C}$ & - & 5.3 & parallel brushed \\
\hline & $\begin{array}{l}\text { rim, } \\
\text {-RO }\end{array}$ & b-h & $\mathrm{F}$ & - & 5.6 & opposed engraved lines \\
\hline & body & $\mathrm{b}$ & $\mathrm{F}$ & E B & 7.5 & plain \\
\hline & body & none & G & I SM & 6.6 & plain \\
\hline \multirow[t]{2}{*}{ Lot 12} & \multicolumn{6}{|c|}{ N99/E90, east profile } \\
\hline & body, Jar & b & B & E SM & 9.3 & plain \\
\hline \multirow[t]{2}{*}{ Lot 14} & \multicolumn{6}{|c|}{ N99/E90, 30-40 cm } \\
\hline & body & $\mathrm{g}$ & B & - & 6.9 & plain \\
\hline \multirow[t]{2}{*}{ Lot 16} & \multicolumn{6}{|c|}{ N99/E90, Feature 1, back dirt } \\
\hline & body & $b$ & B & - & 7.5 & parallel brushed \\
\hline \multirow[t]{5}{*}{ Lot 18} & \multicolumn{6}{|c|}{ N99/E90, Feature 1, undisturbed matrix } \\
\hline & body & sh & $\mathrm{H}$ & - & 4.6 & plain \\
\hline & body & $b-h$ & G & $\mathrm{I} / \mathrm{E} \mathrm{B}$ & 7.3 & plain \\
\hline & body & $\mathrm{b}$ & $\mathrm{B}$ & E SM & 4.3 & plain \\
\hline & body & b-h & B & I SM & 6.3 & parallel brushed \\
\hline \multirow[t]{8}{*}{ Lot 19} & \multicolumn{6}{|c|}{ N99/E90, Feature 1, lower fill } \\
\hline & body & $\mathrm{g}$ & $F^{4}$ & - & 6.3 & plain \\
\hline & body & b-h & $\mathrm{G}$ & I SM & 6.5 & plain \\
\hline & body & $b$ & B & - & 7.9 & plain \\
\hline & body & $\mathrm{b}$ & $\mathrm{H}$ & - & 6.0 & plain \\
\hline & body & $b$ & B & - & 6.0 & parallel brushed \\
\hline & body & $b$ & $\mathrm{G}$ & - & 6.4 & parallel brushed \\
\hline & body & $\mathrm{b}$ & $\mathrm{C}$ & - & 5.9 & parallel brushed \\
\hline
\end{tabular}




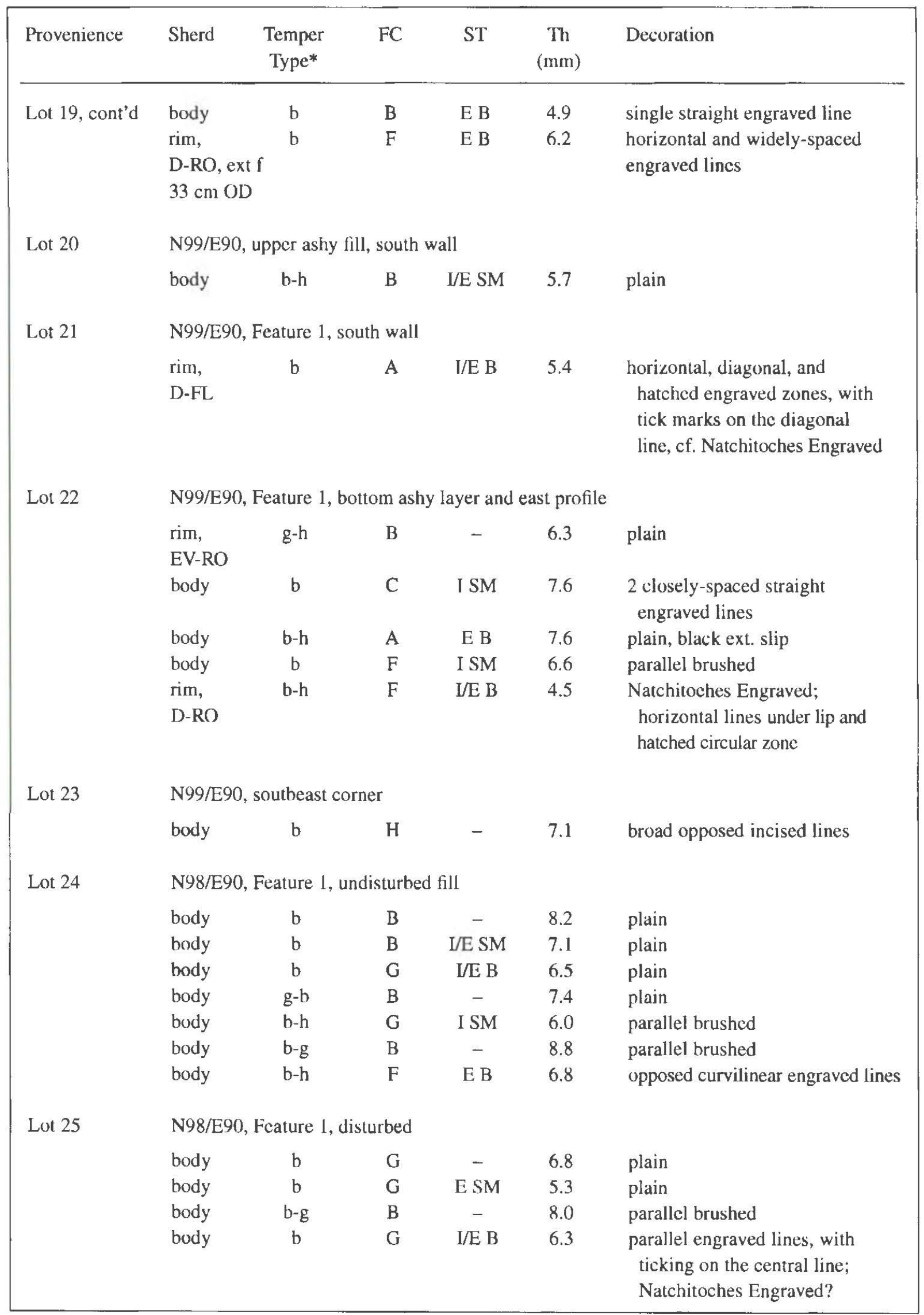




\begin{tabular}{|c|c|c|c|c|c|c|}
\hline Provenience & Sherd & $\begin{array}{l}\text { Temper } \\
\text { Type* }\end{array}$ & FC & ST & $\begin{array}{l}\text { Th } \\
(\mathrm{mm})\end{array}$ & Decoration \\
\hline Lot 25 , con'd & body & b & $\mathrm{G}$ & I/E B & 6.3 & $\begin{array}{l}\text { curvilinear engraved lines, one } \\
\text { with ticking, and hatched } \\
\text { engraved zone, cf. } \\
\text { Natchitoches Engraved }\end{array}$ \\
\hline \multirow[t]{3}{*}{ Lot 26} & \multicolumn{6}{|c|}{ N98/E90, Feature 1, disturbed } \\
\hline & body & $\mathrm{b}$ & $\mathrm{G}$ & I B & 4.5 & $\begin{array}{l}\text { parallel and clusely-spaced } \\
\text { engraved lines }\end{array}$ \\
\hline & $\begin{array}{l}\text { rim, } \\
\text { INV-RO }\end{array}$ & none & B & I/E SM & 5.6 & $\begin{array}{l}\text { small negative engraved oval in } \\
\text { horizontal pancl under the lip }\end{array}$ \\
\hline \multirow[t]{11}{*}{ Lot 31} & \multicolumn{6}{|c|}{ Feature $1,0-10 \mathrm{~cm}$} \\
\hline & $\begin{array}{l}\text { body, } \\
\text { Bt }\end{array}$ & b & $\mathrm{G}$ & E B & 6.5 & plain \\
\hline & body & b & $\mathrm{F}$ & - & 8.0 & plain \\
\hline & body & $b$ & $\mathrm{~F}$ & - & 6.4 & plain \\
\hline & body & $\mathrm{b}$ & $\mathrm{H}$ & E SM & 6.6 & plain \\
\hline & body & sh & B & I SM & 5.4 & multiple parallel incised lines \\
\hline & body & $\mathrm{g}-\mathrm{h}$ & B & I SM & 5.5 & $\begin{array}{l}\text { parallel brushed and straight } \\
\text { appliqued fillet }\end{array}$ \\
\hline & body & b & $\mathrm{F}$ & I SM & 6.6 & parallel brushed-incised \\
\hline & body & b & $\mathrm{G}$ & - & 6.5 & parallel brushed \\
\hline & body & $\mathrm{b}$ & $\mathrm{F}$ & I/E SM & 7.2 & opposed engraved lines \\
\hline & body & b-g & $\mathrm{G}$ & L/E SM & 6.8 & single straight engraved line \\
\hline
\end{tabular}

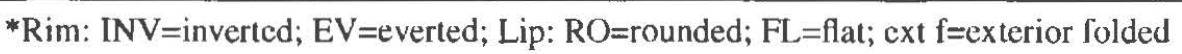

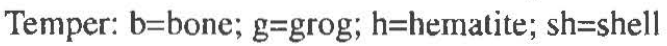

FC=firing conditions, follow Teltser (1993: Figure 2)

$\mathrm{ST}=$ surface treatment; I=interior; E=exterior; $\mathrm{SM}=$ smoothed; $\mathrm{B}=$ burnished

Th=thickness; $\mathrm{Bt}=$ bottle; $\mathrm{OD}=$ orifice diameter

**both sherds are from the same vessel, and are tabulated as one sherd in the main body of the report. 
50 Journal of Northeast Texas Archaeology

\section{APPENDIX 2, INVENTORY OF SHERDLETS}

\begin{tabular}{|lc|}
\hline Provenience & No. of Sherdlets \\
\hline Lot 0 & 17 \\
Lot 1 & 3 \\
Lot 3 & 1 \\
Lot 7 & 11 \\
Lot 11 & 3 \\
Lot 15 & 1 \\
Lot 18 & 4 \\
Lot 21 & 3 \\
Lot 23 & 1 \\
Lot 24 & 7 \\
Lot 26 & 6 \\
Lot 31 & 2 \\
No Lot \# & 1 \\
\hline \multicolumn{1}{|c}{ Totals } & 60 \\
\hline
\end{tabular}

